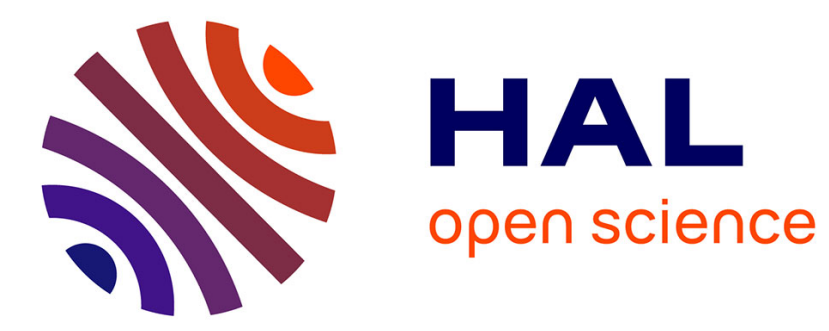

\title{
The impact of economic geography on wages: Disentangling the channels of influence
}

\author{
Laura Hering, Sandra Poncet
}

\section{To cite this version:}

Laura Hering, Sandra Poncet. The impact of economic geography on wages: Disentangling the channels of influence. China Economic Review, 2009, 20 (1), pp.1-14. 10.1016/j.chieco.2008.08.002 . hal-00633816

\section{HAL Id: hal-00633816 https://hal.science/hal-00633816}

Submitted on 20 Oct 2011

HAL is a multi-disciplinary open access archive for the deposit and dissemination of scientific research documents, whether they are published or not. The documents may come from teaching and research institutions in France or abroad, or from public or private research centers.
L'archive ouverte pluridisciplinaire HAL, est destinée au dépôt et à la diffusion de documents scientifiques de niveau recherche, publiés ou non, émanant des établissements d'enseignement et de recherche français ou étrangers, des laboratoires publics ou privés. 
No $2008-20$

October

The impact of economic geography on wages: disentangling the channels of influence

Laura Hering

Sandra Poncet 
The impact of economic geography on wages: disentangling the channels of influence

Laura Hering Sandra Poncet

No $2008-20$

October 
The impact of economic geography on wages: disentangling the channels of influence

\section{Contents}

1 Theoretical framework 10

1.1 Theoretical model: geography and wages $\ldots \ldots \ldots \ldots \ldots$

1.2 The Demand Side . . . . . . . . . . . . . . . . . . . . . . . . . . . . . 10

1.3 The Supply Side. . . . . . . . . . . . . . . . . . . . . . . . . . . 11

1.4 The channels between market access and wages in economic theory . . . . 12

2 Data 14

$2.1 \quad$ Dependent variable . . . . . . . . . . . . . . . . . . . . . . . . . . . . 14

2.2 Independent variables $\ldots \ldots \ldots \ldots \ldots \ldots \ldots$

\begin{tabular}{|lll}
3 & Empirical Results from the wage equation & 17
\end{tabular}

3.1 Wage equation - baseline specification . . . . . . . . . . . . . . 18

3.2 Single-equation approach $\ldots \ldots \ldots \ldots \ldots \ldots \ldots \ldots$

3.3 Multiple-equation approach . . . . . . . . . . . . . . . . . 22

\begin{tabular}{|ll|l}
\hline 4 & Conclusion & 24
\end{tabular}

5 References 25 
THE IMPACT OF ECONOMIC GEOGRAPHY ON WAGES: DISENTANGLING THE CHANNELS OF INFLUENCE

\section{SUMMARY}

This paper evaluates the role of economic geography in explaining regional wages in China. Proximity to markets may impact wages not only directly but also through various indirect channels. Proximity to markets can for instance foster the accumulation of human capital, reinforcing the wage premium for skilled workers in central regions. This effect will occur if intermediate and transport cost-intensive goods use relatively more skilled labor. More central locations where the production of these goods is concentrated will then offer higher wages for skilled labor, which increases the incentives for human capital accumulation (Breinlich, 2006; Faíña and López-Rodríguez, 2006). An analogous mechanism could hold for capital-intensive goods such that capital accumulation may also be affected by spatial proximity and geography centrality.

However, no work to date analyzing the indirect channels of economic geography has computed a proper theory-based measure of market access. This article derives an econometric specification directly from a NEG model to investigate the relevance of market access in China. It builds on previous work which has confirmed the validity of the NEG "wage equation" in China: locations closer to consumer markets (i.e. with greater "market access") experience lower transport costs and enjoy higher income (Cui, 2006; de Sousa and Poncet, 2007; Hering and Poncet, 2008; Lin, 2005; Ma, 2006) (Fujita et al., 1999). The contribution of this article is to disentangle the various channels of influence in order to provide an explanation of the result.

Moving away from single-equation estimates, our results based on a simultaneous-equation system capture the different channels via which economic geography impacts on wages. Variables proxying these various channels (export performance, physical and human capital accumulation) are included in a wage regression. The indirect contribution of market access through the different channels is calculated as the joint effect of market access on the channel and of the channel on wages.

The estimations on 29 Chinese provinces over the 1995-2002 period suggest that access to sources of demand is indeed an important factor in shaping regional wages in China. A one standard deviation rise in market access is associated with a 0.2 standard deviation increase in the annual average wage. A fair share of the market access effect on wages transits via increased incentives for accumulating physical capital and exporting ( 25 and 15 percent of the total effect respectively). Direct transport effects remain however the main source of influence, accounting for almost 60 percent of the total. To better understand the size of these impacts we compute the change in wages were Xinjiang to obtain the same market access as Guangdong (which was ten times larger in 2002). The ten-fold increase in market access in the far-West province of Xinjiang leads to a $60 \%$ rise in wages, bringing Xinjiang level with Zhejiang in third place in China.

Considering that market access has a significant international component, it is likely that, with further integration into the world economy, the already pervasive spatial-wage differences will grow if access to new markets is not evenly distributed across the country. We found that while the wage increasing impact of market access appears on average to be small in magnitude, the wage disparity increasing impact of market access seems to be more significant since high market access provinces are the ones characterized with the most rapid improvement. These inequalities will increase directly through lower trade costs, and indirectly through enhanced incentives to export and accumulate physical capital. 
The impact of economic geography on wages: disentangling the channels of

influence

\begin{abstract}
This paper evaluates the role of economic geography in explaining regional wages in China. It investigates the extent to which market proximity can explain the evolution of wages, and through which channels. We construct a complete indicator of market access at the provincial level from data on domestic and international trade flows; this is introduced in a simultaneous-equations system to identify the direct and indirect effect of market access on wages. The estimation results for 29 Chinese provinces over 1995-2002 suggest that access to sources of demand is indeed an important factor shaping regional wage dynamics in China. We investigate three channels through which market access might influence wages beside direct transport-cost savings: export performance, and human and physical capital accumulation. A fair share of benefits seems to come from enhanced export performance and greater accumulation of physical capital. The main source of influence of market access remains direct transport costs.
\end{abstract}

JEL classification: F12, F15, R11, R12.

Keywords: Economic geography, International Trade, Wage, Trade Openness, Capital accumulation, China. 


\section{L'IMPACT DE L'ÉCONOMIE GÉOGRAPHIQUE SUR LES SALAIRES: DÉCOMPOSITION DES CANAUX D'INFLUENCE}

\section{RÉSUMÉ}

Cet article évalue l'importance de la géographie économique comme déterminant des salaires régionaux en Chine. La proximité aux marchés peut influencer les salaires non seulement de manière directe à travers les coûts de transport mais également indirectement à travers différents canaux (l'accumulation du capital humain, l'accumulation du capital physique et la performance à l'exportation). La proximité des marchés peut par exemple encourager l'accumulation de capital humain, renforçant la prime de salaire des travailleurs qualifiés dans les régions centrales. Cet effet se produit si les intrants de production et intensifs en coûts de transport incorporent relativement plus de travail qualifié. Les localités centrales où est concentrée la production de ces biens offriront des salaires supérieurs aux travailleurs qualifiés, ce qui renforcera les incitations à accumuler du capital humain (Breinlich, 2006; Faíña et López-Rodríguez, 2006). Un mécanisme analogue est vraisemblable pour les produits intensifs en capital de sorte que l'on peut attendre un lien entre centralité géographique et accumulation du capital physique.

Pourtant, aucun travail analysant les canaux indirects de l'économie géographique n'utilise une mesure de l'accès au marché dérivée directement de la théorie. Cet article s'appuie sur une spécification économétrique directement issue d'un modèle de la nouvelle économie géographique (NEG) pour étudier l'importance de l'accès au marché en Chine. Il s'appuie sur les travaux existants validant l' "équation de salaire" de la NEG en Chine à savoir que les localisations proches des marchés de consommation (i.e. dotés d'un "accès au marché" supérieur) supportent des coûts de transport moindres et connaissent des revenus supérieurs (Cui, 2006; de Sousa et Poncet, 2007; Hering et Poncet, 2008; Lin, 2005; Ma, 2006) (Fujita et al., 1999). La contribution de cet article est de dissocier les différents canaux d'impact pour mieux appréhender ce résultat.

Nous construisons un indicateur complet de l'accès au marché au niveau provincial à partir de données de flux commerciaux domestiques et internationaux. Cet indicateur est introduit dans un système d'équations simultanées pour identifier l'impact direct et indirect de l'accès au marché sur les salaires. Le système d'équations simultanées permet d'appréhender les différents canaux (direct et indirects) par lesquels la géographie économique influence les salaires. Il est donc possible de calculer la contribution indirecte de l'accès au marché à travers ces différents canaux comme le produit de l'effet de l'accès au marché sur le canal et de l'effet du canal sur les salaires.

Les estimations couvrant 29 provinces chinoises sur la période 1995-2002 suggèrent que l'accès aux sources de demande est un déterminant important des salaires régionaux en Chine. Une hausse d'un écart-type de l'accès au marché induit une hausse de 0,2 écart-type du salaire annuel. Une grande part de ces bénéfices semble découler d'incitations accrues à exporter et à accumuler du capital physique (25 et $15 \%$ de l'effet total respectivement). Le canal de l'accumulation du capital humain ne paraît par contre pas être important. L'effet direct des coûts de transport apparaît en outre être la source dominante (60\%) de l'effet de l'accès au marché sur les salaires. Pour mieux appréhender l'ampleur de ces impacts on peut calculer la variation de salaires que la province du Xinjiang connaîtrait si elle disposait du même accès au marché que Guangdong (10 fois plus élevé en 2002). Ce décuplement de l'accès au marché dans cette province de l'extrême ouest de la Chine se traduirait par une hausse de $60 \%$ du salaire moyen, plaçant Xinjiang au niveau de Zhejiang (au troisième rang de la Chine).

Dans la mesure où l'accès au marché contient une composante internationale significative, 
il est probable qu'avec l'approfondissement de l'intégration de la Chine dans l'économie mondiale, les inégalités de salaire déjà importantes se renforceront si l'accès aux nouveaux marchés est inégalement réparti au sein du territoire. Tandis que l'effet de l'accès au marché sur la hausse des salaires est plutôt limité, son impact sur l'accroissement des inégalités salariales entre les provinces est important dans la mesure où la hausse de l'accès au marché est plus forte là où l'accès au marché est élevé. Les différences de salaire s'accroîtront en lien direct avec la réduction des coûts de transport et indirectement via l'accroissement des incitations à exporter et à accumuler du capital physique.

\section{RÉSUMÉ COURT}

Cet article évalue l'importance de la géographie économique comme déterminant des salaires provinciaux en Chine. Il étudie dans quelle mesure la proximité des marchés peut expliquer l'évolution des salaires et à travers quels canaux. Nous construisons un indicateur complet de l'accès au marché au niveau provincial à partir de données de flux commerciaux domestiques et internationaux. Cet indicateur est introduit dans un système d'équations simultanées pour identifier l'impact direct et indirect de l'accès au marché sur les salaires. Les estimations couvrant 29 provinces chinoises sur la période 1995-2002 suggèrent que l'accès aux sources de demande est un déterminant important des salaires régionaux en Chine. Nous étudions trois canaux d'impact de l'accès au marché sur les salaires : la performance à l'export et l'accumulation de capital physique et de capital humain. Une grande part de ces bénéfices semble découler d'incitations accrues à exporter et à accumuler du capital physique. Le canal de l'accumulation du capital humain ne paraît par contre pas être important. L'effet direct des coûts de transport apparaît en outre être la source dominante de l'effet de l'accès au marché sur les salaires.

Classification JEL : F12, F15, R11, R12.

Mots Clefs : Economie géographique, salaire, ouverture commerciale, accumulation du capital, Chine. 


\title{
THE IMPACT OF ECONOMIC GEOGRAPHY ON WAGES: DISENTANGLING THE CHANNELS OF INFLUENCE
}

\author{
LAUTA HERING 1 \\ Sandra PONCET ${ }^{2}$
}

\section{Introduction}

In New Economic Geography (NEG) models, the spatial distribution of demand is a key determinant of economic outcomes. Theoretical developments and growing empirical evidence regarding these models (Head and Mayer, 2004; Redding and Venables, 2003 and 2004; and Hanson, 2005) appeal to increasing returns to scale and transport costs to explain the emergence of a heterogeneous economic space ${ }^{3}$ (Krugman, 1991 and 1995). While a number of pieces of work have shown the relevance of market access in the determination of per capita income levels, we understand much less about the precise mechanisms through which this operates.

One central proposition of NEG theory, which is found in the so-called "wage equation", is the importance of proximity to consumers: here nominal wages are modeled as a function of a region's "market access", usually defined as the distance-weighted sum of the market capacity of surrounding locations (Fujita et al., 1999). The underlying idea is that firms located in remoter locations pay higher trade costs on both their sales to final markets and their purchases of intermediate inputs. As such, they earn lower net revenues from export sales ${ }^{4}$ Redding and Venables (2003) carry out theoretical and empirical work at the international level to confirm that external geography is an important determinant of export performance.

Both trade-cost effects consequently imply that remote firms produce less value added with which to remunerate domestic factors of production. Redding and Venables (2004) predict that wages will be higher at the economic center of production, while the periphery will suffer from lower wages. Major recent contributions showing the positive impact of market access on nominal wages include Hanson (2005) for US counties, Mion (2004) for Italy, De Bruyne (2003) for Belgium, Brakman et al. (2004) in 114 German districts, and Head and Mayer (2006) and Breinlich (2006) using European Union data.

\footnotetext{
${ }^{1}$ CES-Universités de Paris 1.

${ }^{2}$ Corresponding author: Centre d'Economie de la Sorbonne, Université Paris 1, CNRS and CEPII.

${ }^{3}$ These trade costs include not only the expense of physically moving products between locations but also all information costs and tariffs associated with transacting at a distance (Redding and Schott, 2003).

${ }^{4}$ Note that an additional access penalty will apply if production uses intermediate inputs which have to be imported over long distances.
} 
Besides this direct effect, proximity to markets may impact wages also through various indirect channels. To capture potential indirect effects of economic geography on wages of EU regions, Breinlich (2006) includes control variables for human and physical capital accumulation. The impact of proximity to markets on the accumulation of human capital, reinforcing the wage premium for skilled workers in central regions has been shown by Redding and Schott (2003). This effect will occur if intermediate and transport cost-intensive goods use relatively more skilled labor. More central locations where the production of these goods is concentrated will then offer higher wages for skilled labor, which increases the incentives for human capital accumulation. The empirical findings of Breinlich (2006) and Faíña and López-Rodríguez (2006) confirm the theoretical importance of economic geography in explaining the spatial structure of educational attainment levels in the EU. Breinlich (2006) and López-Rodríguez and Faíña (2006) suggest that an analogous result should hold for capital-intensive goods, and find that capital accumulation is also affected by spatial proximity and geography centrality.

However, no work to date analyzing the indirect channels of economic geography has computed a proper theory-based measure of market acces 5 , leaving much room for future work to improve upon the approach before a final verdict can be announced. Data limitations due to the unavailability of intranational trade flows data have often precluded the construction of a structural version of market access.

Chinese provinces are a fortunate exception, with the decomposition of trade flows between international and domestic partners being available at the provincial level, allowing us to construct a very complete measure of market access. This article derives an econometric specification directly from a NEG model to investigate the relevance of market access in China. Recent work on Chinese data (Cui, 2006; de Sousa and Poncet, 2007; Hering and Poncet, 2008; Lin, 2005; Ma, 2006) has confirmed the validity of the NEG "wage equation": locations closer to consumer markets (i.e. with greater "market access") experience lower transport costs and enjoy higher income (Fujita et al., 1999). Most of the work on China cited above relies on province-level market access and income data, although the positive relationship between market access and wages has also been confirmed at the micro level (Hering and Poncet, 2008).

While this work has concluded that market access is an important determinant of wages, the various channels of influence have not been disentangled in order to provide an explanation of the result.

We employ a fully-specified empirical model to evaluate the channels through which market access might affect wages. Moving away from single-equation estimates, our results based on a simultaneous-equation system capture the different channels via which economic geography impacts on wages. Variables proxying these various channels (export performance, physical and human capital accumulation) are included in a wage regression. The indirect contribution of market access through

\footnotetext{
${ }^{5}$ López-Rodríguez and Faína (2006) rely on the Harris formula of the distance-weighted sum of regional GDPs, while Breinlich (2006) proxies regional expenditures by gross value added.
} 
the different channels is calculated as the joint effect of market access on the channel and of the channel on wages.

We construct market access indicators at the provincial level from data on domestic and international trade flows, and control for provincial fixed effects so as to focus on the impact of market access on provincial wages over time.

The estimations on 29 Chinese provinces over the 1995-2002 period suggest that access to sources of demand is indeed an important factor in shaping regional wages in China. A fair share of the benefits seem to come from increased incentives to export and accumulate physical capital. On the contrary, the accumulation of human capital does not seem to play a major role. Direct transport costs remain the main source of market access influence.

The paper is organized as follows. The following section outlines a theoretical framework for the direct and indirect impact of market access on wages from which the econometric specifications used in the subsequent sections are derived. Section 2 describes the data sources and variable construction. Section 3 investigates the direct and indirect effects of market access on wages in China, and attempts to disentangle the different channels through which market access affects wages. Section 4 concludes.

\section{Theoretical framework}

\subsection{Theoretical model: geography and wages}

The theoretical framework underlying the empirical analysis is a reduced version of a standard New Economic Geography model of monopolistic competition based on Dixit and Stiglitz (1977), similar to that used by Fujita et al. (1999) and Redding and Venables (2004).

\subsection{The Demand Side}

We consider a world with $R$ locations, composed of firms operating under increasing returns to scale and producing differentiated manufactured products. Consumer utility increases with the number of varieties. The demand for differentiated products is modeled in the usual symmetric constant elasticity of substitution way, with $\sigma$ being the elasticity of substitution between any pair of products. The final demand for goods in $j$ is derived from the maximization of the representative consumer's CES utility function ${ }^{6}$ Country $j$ 's demand for a variety produced in $j$ is:

$$
\operatorname{Demand}_{i j}=p_{i j}^{-\sigma} G_{j}^{\sigma-1} E_{j},
$$

where $E_{j}$ is the expenditure of region $j, p_{i j}$ is the c.i.f. price of a variety produced in $i$ and sold in $j$ and $G_{j}$ is the CES price index for manufactured goods, defined over

\footnotetext{
${ }^{6}$ See Fujita et al. (1999) for a complete statement of the underlying model.
} 
the c.i.f. prices:

$$
G_{j}=\left[\sum_{i=1}^{R} n_{i} p_{i j}^{1-\sigma}\right]^{1 / 1-\sigma} .
$$

\subsection{The Supply Side}

Transporting manufactured products from one region to another is costly. The iceberg transport technology assumes that $p_{i j}$ is proportional to the mill price $p_{i}$ and shipping costs $T_{i j}$, so that for every unit of good shipped abroad, only a fraction $\left(\frac{1}{T_{i j}}\right)$ arrives. Thus, the demand for a variety produced in $i$ and sold in $j$ eq. 1 , can be written as:

$$
\text { Demand }_{i j}=\left(p_{i} T_{i j}\right)^{-\sigma} G_{j}^{\sigma-1} E_{j} .
$$

We follow the literature in referring to $\phi_{i j}=T_{i j}^{1-\sigma}$ as the "phi-ness" of trade (see Baldwin et al., 2003). This takes values between 0 (when trade costs are prohibitive) and 1 (when trade costs are negligible). Summing over all the products produced in location $i$, we obtain the "trade equation" (Redding and Venables, 2004).

The value of total exports of region $i$ to region $j$ is therefore:

$$
n_{i} p_{i} x_{i j}=n_{i} p_{i}^{1-\sigma} \phi_{i j} G_{j}^{\sigma-1} E_{j}
$$

As emphasized by Redding and Venables (2003), this equation for bilateral trade flows provides the basis for the estimation of a gravity trade model. While the last term on the right-hand side of equation (4) contains the "market capacity" of region $j, m_{j}=G_{j}^{\sigma-1} E_{j}$, the first term, $n_{i} p_{i}^{1-\sigma}$, measures what is referred to as the "supply capacity" of the exporting region, $s_{i}=n_{i} p_{i}^{1-\sigma}$. This corresponds to the product of the number of varieties with their price competitiveness 7

The bilateral trade flows equation (4), which will serve as the basis of the gravity equation estimated in Section 2.2.2, can therefore be expressed simply as:

$$
n_{i} p_{i} x_{i j}=s_{i} \phi_{i j} m_{j}
$$

To determine the total sales, $q_{i}$, of a representative firm in region $i$, we sum sales across regions, given that total shipments to one region are $T_{i j}$ times quantities consumed:

$$
q_{i}=\sum_{j=1}^{R}\left(p_{i} T_{i j}\right)^{-\sigma} G_{j}^{\sigma-1} E_{j} T_{i j}=p_{i}^{-\sigma} M A_{i}
$$

where

$$
M A_{i}=\sum_{j=1}^{R} T_{i j}^{1-\sigma} G_{j}^{\sigma-1} E_{j},
$$

\footnotetext{
${ }^{7}$ Redding and Venables (2003) discuss the concepts of market and supply capacity in greater depth.
} 
represents the market access of each exporting region $i$ (Fujita et al., 1999). Each firm $i$ has profits $\pi_{i}$, assuming that the only input is labor:

$$
\pi_{i}=p_{i} q_{i}-w_{i} \ell_{i},
$$

where $w_{i}$ and $\ell_{i}$ are the wage rate and the labor demand for manufacturing workers, respectively ${ }^{8}$ We assume that the labor requirement, $\ell$, depends on output, $q$, as follows:

$$
\ell_{i}=\left(F+c q_{i}\right)
$$

where $F$ and $c$ represent the fixed and marginal requirements in labor units. Replacing (9) in (8) and maximizing profits yields the familiar mark-up pricing rule:

$$
p_{i}=\frac{\sigma}{\sigma-1} c w_{i}
$$

for the varieties produced in region $i$. Given the pricing rule, profits are:

$$
\pi_{i}=w_{i}\left[\left(\frac{c q_{i}}{\sigma-1}\right)-F\right] .
$$

We assume that free entry and exit drive profits to zero. This condition implies that the equilibrium output of any firm is:

$$
q^{*}=\frac{F(\sigma-1)}{c} .
$$

Using the demand function (6), the pricing rule (10) and equilibrium output (12), we calculate the manufacturing wage when firms break even:

$$
w_{i}=\frac{\sigma-1}{\sigma c}\left[M A_{i} \frac{c}{F(\sigma-1)}\right]^{1 / \sigma}=\alpha\left[M A_{i}\right]^{1 / \sigma} .
$$

Equation (13) relates location $i$ 's wage level to its market access. This is the second key relationship that will be estimated in section 3 .

\subsection{The channels between market access and wages in economic theory}

There is growing empirical evidence supporting the theoretical prediction of equation (13) in China. Provinces with good market access exhibit higher per capita income than peripheral provinces (Lin, 2005; de Sousa and Poncet, 2007).

The precise mechanisms through which access to sources of demand shapes regional incomes are less clearly understood. Beside the direct transport cost savings accruing to central locations, the literature has proposed at least three channels through which market access might influence economic outcomes (Breinlich, 2006; Redding and

\footnotetext{
${ }^{8}$ Perfect competition in the agricultural sector implies marginal-cost pricing, so that the price of the agricultural good $p^{A}$ equals the wages of agricultural laborers $w^{A}$. We choose good $\mathrm{A}$ as the numeraire, so that $p^{A}=w^{A}=1$.
} 
Venables, 2003; Redding and Schott, 2003): export performance, human-capital accumulation and physical-capital accumulation.

A primary channel is unveiled by writing region $i$ 's exports as the sum of equation (5) over all partners:

$$
\sum_{j} n_{i} p_{i} x_{i j}=n_{i} p_{i}^{1-\sigma} \sum \phi_{i j} G_{j}^{\sigma-1} E_{j}=s_{i} M A_{i}
$$

A region's exports turn out, as shown by Redding and Venables (2003), to be the product of its supply capacity $s_{i}$ and market access $M A_{i}$. The fact that firms in remote locations pay greater trade costs for exports will either push up their export prices or reduce the amount of residual value added, so that exports will be discouraged. Worse export performance may in turn affect economic outcomes, in line with the positive correlation generally found between trade openness and per capita income 9 Some theories stress technological spillovers and the international transmission of knowledge as sources of growth for open economies. The models in Grossman and Helpman (1991) and Barro and Sala-i-Martin (1997) for instance rely on the notion that more open economies are better able to import advanced technologies. Trade openness may moreover create incentives for governments to adopt less distortionary domestic policies and more disciplined types of macroeconomic management. Wacziarg (2001) suggests a positive impact of openness on economic growth, with greater accumulation of physical capital accounting for over half of the total effect, and enhanced technology transmission and improvements in macroeconomic policy accounting for smaller parts. Controlling for sharpened incentives for physical capital accumulation (the third channel), we investigate whether provinces with better market access export more, and whether this brings additional benefits such as technological spillovers and improvements in macroeconomic policy that are not captured in the model developed above ${ }^{10}$

Redding and Schott (2003) highlight an additional penalty of remoteness relating to incentives for human-capital accumulation. They show that being located on the economic periphery may reduce the return to skill, thereby reducing the incentive to invest in human capital. If skill-intensive sectors have higher trade costs, more pervasive input-output linkages, or greater increasing returns to scale, they will disproportionately locate in high market access regions. Redding and Schott (2003) show theoretically, and check empirically, that remoteness not only diminishes contemporaneous factor rewards, but also discourages human-capital accumulation and reduces the supply of high-income skilled workers. This additional penalty is argued to occur if intermediate- and transport cost-intensive goods are relatively intensive users of that factor of production.

Since it seems a priori reasonable that similar conditions hold for capital-intensive goods, centrality might also impact positively on physical-capital accumulation. Some

\footnotetext{
${ }^{9}$ See for instance Edwards (1992), Frankel and Romer (1999), Alesina et al. (2000) and Wacziarg (2001).

${ }^{10}$ We thank an anonymous referee for suggesting this point.
} 
evidence that stocks of human and physical capital are highly correlated with market access in the EU regions is advanced in Breinlich (2006) and López-Rodríguez and Faíña (2006).

\section{Data}

The core empirical part of this paper relates wages in Chinese provinces to market access. We first describe the data sources for the dependent variable, provincial wage, and the construction of the explanatory variables. Appendix A describes the data sources in greater detail.

\subsection{Dependent variable}

We consider 29 Chinese provinces between 1995 and 2002 ${ }^{11}$ Our dependent variable is the average regional wage rate of workers and staff, defined as the ratio of the wage bill to the number of workers and staff in the province. Tables A-1 and A-2 present some summary statistics. Table A-2 stresses that provincial wages increased very rapidly over the sample period (1995-2002). The average growth rate is about $13 \%$ per year over the period. By contrast, he average growth rate of market access of Chinese provinces is far much lower at $1.1 \%$ per year over the period.

Map 1 in Appendix A shows the distribution of estimated provincial market access and average wages in 2002. Figures 1 and 2 in Appendix A graph wages as a function of market access separately for the two end years of our sample (1995 and 2002). Both the map and the graphs make apparent that greater market access is found in high-wage provinces, in line with the theoretical prediction of the wage equation in the NEG model.

\subsection{Independent variables}

\subsubsection{Market access}

Our key explanatory variable is $M A_{i}$, the market access in each Chinese province $i$. As shown in equation (7), market access is defined as $M A_{i}=\sum_{j} \phi_{i j} G_{j}^{\sigma-1} E_{j}$. Since neither market access itself nor its components, market capacity $\left(G_{j}^{\sigma-1} E_{j}\right)$ and freeness of trade $\left(\phi_{i j}\right)$, are directly observable, we rely on the two-step procedure pioneered by Redding and Venables (2004). We therefore estimate the market capacities, $m$, of international and national trading partners as well as transport costs, $\phi$, using a gravity equation.

Taking natural logarithms in Equation (5) yields the basic econometric specification used for the trade equation, where the total value of exports to region $j$ from all firms based in region $i$ is given by:

\footnotetext{
${ }^{11}$ Our analysis covers all of the provinces apart from Tibet, Hainan and Chongqing.
} 


$$
\ln \left(X_{i j}=n_{i} p_{i} x_{i j}\right)=\ln s_{i}+\ln \phi_{i j}+\ln m_{j}=F X_{i}+\ln \phi_{i j}+F M_{j}
$$

The empirical estimation of equation (15) will provide us with estimates of the two components of market access: freeness of trade and market capacity. Importer fixed effects correspond to the log of the unobserved market capacity of the importing region $j, F M_{j}=\ln m_{j}=\ln \left(G_{j}^{\sigma-1} E_{j}\right)$, while exporter fixed effects $\left(F X_{i}\right)$ capture the log of the exporter's supply capacity, $\ln s_{i}$.

In the next subsection (2.2.2) we estimate the gravity equation. The resulting parameter estimates are then used to compute market access for each Chinese province (Subsection 2.2.3).

\subsubsection{Estimation of the trade equation}

To estimate the trade equation, we rely on a number of different data sources to construct our bilateral trade flows data set covering intra-provincial, inter-provincial, international and intra-national trade flows 12

All trade flows are merged into a bilateral trade flows data set covering 29 Chinese provinces and around 200 countries of the rest of the world $(R O W)$. The estimate of Equation (15) based on this complete data set allows us to compute the market capacities of Chinese provinces and foreign countries based on their exports to all destinations (domestic and international) 13

Following previous work on the border effects of Chinese provinces, we allow the impediments to domestic trade to be different from those to international trade (Poncet, 2003) 14 In our gravity equation, transport costs are therefore assumed to depend on both bilateral distances and a series of dummy variables indicating what type of border has been crossed.

Allowing border effects to vary according to the trading partner, equation (15) yields the following trade regression, where $B$ denotes dummies:

$$
\begin{aligned}
& \ln X_{i j}=F X_{i}+F M_{j}+\delta \ln d_{i s t} t_{i j}+\varphi B_{i j, i \text { or } j \in \text { China }}^{\text {foreign }}+\varphi^{*} B_{i j, i \& j \in R O W}^{f o r e i g n} \\
& +\psi \text { Contig } i j+\vartheta B_{i j, r \neq j, i}^{\text {provincial } i \text { \& } j \in \text { China }}+\xi B_{i j, i=j, i \& j \in R O W}^{\text {intranational }}+\zeta_{r j}
\end{aligned}
$$

\footnotetext{
${ }^{12}$ See Appendix A for details of the data sources for the trade flows and production indicators for Chinese provinces and international countries used to estimate the trade equation.

${ }^{13}$ All available trade flows are included in the trade equation estimation to properly measure the market capacity of foreign countries (i.e. their demand toward all destinations, and not only toward China). To account for heterogeneity in trade costs between different parts of the sample, we allow for differentiated transport costs depending on whether trade occurs between a Chinese province and foreign countries, between two foreign countries, between a Chinese province and the rest of China, within foreign countries or within foreign Chinese provinces (see Equation 16).

${ }^{14}$ Poncet (2003) finds the domestic and international border effects of Chinese provinces to be around $27=[\exp (3.30)]$ and $400=[\exp (6)]$ respectively in 1997. See Poncet (2003 and 2005), for more detail on the existence, level and evolution of impediments to inter-provincial trade in China.
} 
This equation literally says that we allow transport costs to differ according to whether trade occurs between a Chinese province and foreign countries $\left(\delta \ln \operatorname{dist}_{i j}+\varphi+\right.$ $\psi$ Contig $\left._{i j}\right)$, between two foreign countries $\left(\delta \ln d i s t_{i j}+\varphi^{*}+\psi\right.$ Contig $\left._{i j}\right)$, between a Chinese province and the rest of China $\left(\delta \ln d i s t_{i j}+\vartheta\right)$, within foreign countries $\left(\delta \ln d i s t_{i i}+\xi\right)$ or within Chinese provinces $\left(\delta \ln d i s t_{i i}\right)$. For these last two cases, only internal distance affects trade freeness. The distance of a Chinese province or a foreign country to itself is modeled as the average distance between producers and consumers in a stylized representation of regional geography, which is distance $_{i i}=\left(2 / 3 \sqrt{\text { area }_{i i} / \pi}\right)$. In the case of inter-provincial and international trade flows, dist ${ }_{i j}$ is measured as the great circle distance between $i$ and $j$. Being neighbors dampens the border effect (Contig $g_{i j}=1$ for contiguous pairs of partners). Equation (16) is estimated for each of the eight years of our sample, yielding year and country/region-specific estimates to construct Chinese provinces' market access. The results for 1995, 1999 and 2002 appear in Table $1 \stackrel{15}{15}$ The estimated coefficient on distance is similar to those found in the related literature, as is the impact of contiguity. We confirm the findings from Poncet (2003) that the border effect inside China is important. Further, impediments to trade are found to be greater between China and the Rest of the World than between countries included in our sample (which are mostly members of the WTO and are therefore much more integrated in the world economy than was China in the 1990s).

\subsubsection{Calculating Market Access}

The market access of province $i$ to all regions and countries $j$ (including itself) consists of three components, corresponding to the three elements in equation (17): provincial market access, national market access (from all other Chinese provinces), and Rest of the World $(R O W)$ market access. Formally, the market access of province $i$ is given by:

$$
\begin{aligned}
M A_{i}= & \phi_{i i} G_{i}^{\sigma-1} E_{i}+\sum_{j \in \text { China }} \phi_{i j} G_{j}^{\sigma-1} E_{j}+\sum_{j \in R O W} \phi_{i j} G_{j}^{\sigma-1} E_{j} \\
& =\text { dist }_{i i}^{\delta} \exp \left(F M_{i}\right)+\sum_{j \in \text { China }} d i s t_{i j}^{\delta} \exp (\vartheta) \exp \left(F M_{j}\right) \\
& +\sum_{j \in \text { ROW }} d i s t_{i j}^{\delta} \exp \left(\varphi+\psi \text { Contig }_{i j}\right) \exp \left(F M_{j}\right)
\end{aligned}
$$

where $F M_{j}$ and the parameters $\delta, \vartheta, \varphi$ and $\psi$ are estimated in the trade equation. Local market access accounts for the largest share of $M A(58.6 \%)$ above national and foreign market access of $33.8 \%$ and $7.5 \%$ respectively. As own-region market access may be particularly endogenous to local wages, our empirical work appeals

\footnotetext{
${ }^{15}$ Importer and exporter fixed effects are included in the regression, which capture the border effect within foreign countries $\left(\delta \ln d i s t_{r j}+\xi\right)$. The omitted category in the regression is within Chinese province trade.
} 
to two different methods to address any simultaneity. First, we instrument market access. Second, we exclude the local part of market access and compute $M A$ solely as the sum of market capacity of foreign partners and the rest of China. Our results suggest that the relationship between market access and wages is not entirely driven by "own-region market access".

\subsubsection{Indicators of the indirect impact channels}

The three channels through which market access is expected to influence wages (export performance, human capital and physical capital) can be captured in fairly uncontroversial ways as far as measurement is concerned.

Export performance ExpPerf is calculated as the ratio of exports over GDP.

Human-capital accumulation $H u m K$ is proxied by the share of population with at least secondary education. The annual stock of people with at least this level of education is computed using data on the number of people with various education levels from the population Census of China and from annual sample surveys of population changes. Neither of these sources are available in some years, so we build on the previous estimate of the stock using the permanent inventory procedure of Démurger (2001) with data on the yearly number of graduates by education level and provincial mortality rates.

The physical capital stock $K$ is computed via the perpetual inventory method with a depreciation rate $\delta$ of five percent. We rely on the following formula: $K_{i, t+1}=$ $K_{i, t}+I_{i, t}-\delta K_{i, t}$. We derive an initial estimate of the capital stock for 1974, the first year for which data on investment flows are available, following Harberger (1978). This method is based on the hypothesis that in 1974 each province was at its steadystate capital-output ratio ${ }^{16}$ Our final measure is the physical capital stock PhysK per employee.

\section{Empirical Results from the wage equation}

This section describes the estimation of the wage equation (Equation 13) derived in Section 1.3. The baseline specification is discussed in the next subsection (3.1). In the following subsections ( 3.2 and 3.3), we then propose two alternative ways of disentangling the direct and indirect effects (via human and physical capital, and export performance) of market access on wages. In subsection 3.2, we include indicators of indirect effects directly into the baseline wage specification, purging the coefficient on market access of these indirect effects. Equally, the impact of $M A$ on education, physical capital and export performance can be evaluated through separate regressions. This is done in subsection 3.3 by using a simultaneous equations system to

\footnotetext{
${ }^{16}$ As argued by Beck et al. (2000), while this assumption is surely wrong, it is better than assuming an initial capital stock of zero, which many researchers have done. Alternative measures of capital growth based on assuming an initial stock of zero actually produce similar results.
} 
identify the effect of market access on wage and the channels through which this effect passes.

\subsection{Wage equation - baseline specification}

Log-linearizing Equation (13) from Section 1.3, introducing a time dimension $\mathrm{t}$, and controlling for time-invariant provincial effects $\eta$ and common time effects $\lambda$ yields the following specification:

$$
\ln w_{i t}=a_{i}+b \ln M A_{i t}+\eta_{i}+\lambda_{t}+\epsilon_{i t}
$$

We estimate Equation (18) for 29 provinces over the period 1995-2002. Column 1 in Table (2) reports the OLS results from this baseline specification (without province fixed effects). Year dummies are included to capture phenomena common to all provinces, such as national total factor productivity growth and external shocks. Market access is statistically significant at the $1 \%$ level with a coefficient of 0.16 . On average, a $10 \%$ increase in provincial market access leads to $1.6 \%$ higher wages. The estimated $M A$ elasticity of $16 \%$ is in line with that in other work (de Sousa and Poncet, 2007) and with the theoretical prediction. The structural derivation of our market access variable provides us with a theoretical interpretation of its estimate. Theoretically, this figure corresponds to $1 / \sigma$, where $\sigma$ is a measure of product differentiation, increasing returns to scale and the degree of market competition (Head and Mayer, 2004). Our estimate of 0.16 corresponds to $\sigma=6.25$, which is in line with existing results. Empirical estimates of $\sigma$ typically lie between 5 and 10, depending on the estimation methodology (Erkel-Rousse and Mirza, 2002, and Head and Ries, 2001).

As there are significant provincial differences in policies, endowments and development in China, Column 2 introduces province fixed effects to take this heterogeneity into account. This new specification explains a greater part (up from 87 to 95\%) of the variance in provincial wages. As expected, the inclusion of province fixed effects leads to a reduction in both the size and the significance of market access. However, it remains both statistically and economically significant. On average, doubling market access increases average wages by approximately $6 \%$, which is in line with the results obtained based on city level data by Hering and Poncet (2007). This corresponds to the total effect, including both the direct and indirect channels. We might be tempted to conclude that the above wage estimates underscore the relevance of NEG models. However, a significant impact of market access is also consistent with urban agglomeration theories. Hanson (2005) lists three alternative mechanisms to market access linking agglomeration and wages: (1) non-human factor endowments; (2) increasing returns external to firms; and (3) human capital externalities.

With respect to the first, we assume that differences in institutions and technology are likely to evolve only slowly and respond in particular to national-level reforms. As such, we expect these to be picked up in the province and year fixed effects. 
The second and third mechanisms correspond to two main competing agglomeration dynamics. On the one hand, the bigger and/or denser is an agglomeration (in terms of labor), the more knowledge spillovers there are between firms and workers. This leads to greater worker productivity and therefore higher wages. On the other hand, large agglomerations often exert a downward pressure on prices because of tougher competition between a greater number of producers who all want to sell their products. Lower prices drive down wages. Larger provinces are therefore exposed to these two contradictory forces.

To see whether our $M A$ results reflect size effects caused by spillovers between firms or human-capital externalities, the regression in Column 3 of Table 2 introduces two additional control variables, namely population density and the children dependency ratio (population aged under 15 over population aged between 15 and 64). This latter attracts a significant negative coefficient, whereas population density is insignificant. This might show that the two competing forces above offset each other. In any case, the effect of $M A$ on wages is virtually unchanged.

Our next step is to address potential simultaneity. Market access, on the right-hand side of the estimated equation, is a weighted sum of all potential expenditures, including local ones. These expenditures depend on income, and therefore on wages, raising concerns of reverse causality in the estimation. A positive shock to $w_{i}$ may well increase $E_{i}$ and consequently $M A_{i}$. This is all the more likely as own-province market access is the main component of $M A$, as noted above. As a first robustness test, Column 4 of Table 2 introduces market access computed solely as the sum of the market capacities of foreign partners and the rest of China. This "Non-Local Market access" exerts a positive and significant effect on wages, so that the effect of market access is not entirely driven by "own-region market access".

Our second strategy to address simultaneity relies on instrumental variables. The literature to date has attempted to resolve the simultaneity problem by considering variations in market access due to geography. Redding and Venables (2004) use the distance to the nearest central place (Brussels, New York City, or Tokyo), and Head and Mayer (2006) use measures of location "centrality" obtained by dividing the surface of the globe into approximately 11,700 squares. Both measures can reasonably be assumed to be exogenous to potential wage shocks since they do not incorporate any information on regional market size. However, they have the disadvantage of being time-invariant, and as such can only explain the cross-section dimension of market access. Column 5 of Table 2 presents the cross-sectional results à la Head and Mayer (2006) for 2000. The results confirm the significant effect of $M A$ on wages, even though there are only very few observations (29 provinces). Our main interest is the within dimension of our sample. As such, we take a different approach and appeal to two time-varying demand instruments relative to province $i$ at time $t$. The first is the weighted distance to importing partners, the weights being the shares of provincial exports: $I_{M A_{i t}^{1}}=\sum_{j} \frac{1}{\text { distance }_{i j}} \frac{\text { exports }_{i j t}}{\sum_{j} \text { exports }_{i j, t}}$. The second is the weighted average of the nominal exchange rate $(N E R)$ of importing partners, computed as: $I_{M A_{i t}^{2}}=\sum_{j} \mathrm{NER}_{i j t} \frac{1}{\text { distance }_{i j}}$. The weighting of $N E R_{i j}$ reflects 
the bilateral distance between $i$ and $j$. Both instruments appeal to the great circle distance between the capital cities in province $i$ and country $j$. We argue that a nominal devaluation (appreciation) of country $j$ 's currency vis-à-vis the Chinese yuan translates in a fall (rise) in $j$ 's demand for Chinese products ${ }^{17}$ The effect of this change differs across Chinese provinces, depending on each province's distance to the partner $j$.

The $M A$ coefficient from the IV estimates is shown in Column 6 of Table 2. We systematically check the validity of our instruments via Hansen's J-test of overidentifying restrictions. Insignificant test statistics indicate that the orthogonality of the instruments and the error terms cannot be rejected, and thus that our choice of instruments is appropriate ${ }^{18}$ We complement this test, which can suffer from low power, especially in the context of relatively few observations and potentially weak instruments (Bowsher, 2002), by the Partial $\mathrm{R}^{2}$ of excluded instruments and the first-stage F-test (with degrees of freedom corresponding to the number of regressors in the first-stage regression). We also report the F-stat form of the Cragg-Donald statistic; this is suggested by Stock and Yogo (2002) as a global test for the presence of weak instruments (i.e. it tests the null hypothesis that a given set of instruments is weak against the alternative that it is strong). This statistic is also reported together with the critical values based on a $5 \%$ and $10 \%$ maximum bias of the IV estimator relative to the OLS at the 5\% confidence level, as tabulated by Stock and Yogo (2002). The test rejects the null hypothesis if the computed statistic exceeds the critical value. The results with respect to instrument quality are overall satisfactory. The Davidson-MacKinnon test, which tests for the endogeneity of the market access indicator in this IV regression, does not reject the null hypothesis of exogeneity of market access (at the 10\% confidence level). Consequently the following Sections report OLS estimates since these are more efficient than IV estimates (Pagan, 1984). Having confirmed the positive and significant impact of $M A$ on wages, we now try to disentangle the direct and indirect channels of impact.

\subsection{Single-equation approach}

A straightforward way of identifying potential channels of $M A$ impact is adopted by Breinlich (2006) and López-Rodríguez and Faíña (2006). This consists of the inclusion of proxies for the potential channels as additional regressors in the baseline wage specification. Columns 7 to 9 of Table 2 show the corresponding results. Indicators of human capital, physical capital and export performance are successively introduced.

The direct influence of market access is much smaller than that in the benchmark

\footnotetext{
${ }^{17}$ We argue that movements in China's partners' exchange rates are mostly driven by national factors and are thus exogenous to income in Chinese provinces. As such, weighted with distance between provinces and international partners they are relevant instruments for provincial MA.

${ }^{18}$ Under the joint null hypothesis that instruments are valid and that the excluded instruments are correctly excluded from the estimated equation, the test statistic is distributed as $\chi^{2}$ in the number of other identifying restrictions. Significance is judged at the $10 \%$ level.
} 
results (in Column 2). The inclusion of both export performance and capital accumulation significantly reduces the coefficient on $M A$. When all three indirect channel measures are included together, the market access coefficient falls to 0.04, which is about two-thirds of the initial estimate. However, it remains both statistically significant at the $10 \%$ level and economically important. The sign and size of the other coefficients also seem plausible. A doubling of the capital stock per capita raises wages by around $25 \%$, while doubling both the share of the workforce with secondary education and export performance increases wages by about $5 \%$.

We evaluate the impact of $M A$ on the three indirect channels via separate regressions reported in Table 3 . We systematically address the endogeneity of $M A$ using the two instruments presented in the previous section. The bottom rows of Table 3 report Hansen's J-test of overidentifying restrictions, the Cragg-Donald test for weak identification 19 , and the Davidson-MacKinnon test, which tests the endogeneity of market access indicator in a IV regression. Significant test statistics mean that the orthogonality of the instruments and the error terms and the null hypothesis of exogeneity of the market access are rejected. The more efficient OLS estimates are reported (Pagan, 1984).

The results show that market access has a significant impact on physical capital stock per capita as well as on outward orientation. However, it does not seem to influence the share of population with high education. With respect to the control variables, while age composition does not impact wages directly (as shown in Table 2), it does turn out to be a significant determinant of human capital and export performance. Favorable climate conditions for agriculture, as proxied by average temperature, turn out as expected to have a negative impact on human and physical capital, which are more likely to be fundamental inputs of the non-agricultural activities in which wage earners concentrate. The indicators of government presence are intended to capture two particular features of the Chinese economy. First, the economic share of state entities in industrial output is typically considered in the literature to be an indicator of the progress of reform, and is consequently expected to be negatively correlated with economic performance in general. This prediction is borne out by the negative estimated effect of the importance of public output on export performance. On the other hand, it is often found that the share of state entities has a positive impact on investment in physical capital, since state entities are traditionally characterized by greater capital intensity and investment inefficiency (Naughton, 2007). We find in column 2 of Table 3 that the share of state entities in investment has positive but insignificant effect on physical capital accumulation.

Overall, market access appears to have a greater impact on export performance than on factor accumulation. On average, doubling market access increases the export rate and capital stock per capita by approximately $20 \%$ and $5 \%$, respectively.

\footnotetext{
${ }^{19}$ Our first stage F-statistics are consistently above 10, consistent with Staiger and Stock's (1997) "rule of thumb".
} 


\subsection{Multiple-equation approach}

We here test the robustness of the above results based on single equations using a system of simultaneous equations. This system describes the incidence of market access on wages directly and indirectly via three channels. The various equations capture the different theoretical arguments as to the potential indirect effects of market access on wages presented above.

By multiplying the effects of market access on the channel, and the effect of the channel on wages, the impact of market access on wages through any particular channel can be identified. This approach is inspired by a method first employed in the cross-country growth context by Tavares and Wacziarg (2001) and Wacziarg (2001) to analyze the effects of democracy and trade policy respectively on economic growth.

The model consists of a set of five equations.

$$
\begin{aligned}
\ln w_{i t}= & \alpha^{1} \ln M A_{i t}+\beta^{1} \ln \operatorname{Phys}_{i t}+\gamma^{1} \operatorname{HumK}_{i t} \\
& +\delta^{1} \ln \operatorname{ExpPerf}_{i t}+\eta_{i}^{1}+\lambda_{t}^{1}+\epsilon_{i t}^{1}(1) \\
\ln \operatorname{Phys}_{i t}= & \alpha^{2} \ln M A_{i t}+\phi^{2} \operatorname{CONTROL} S_{i t}^{2}+\eta_{i}^{2}+\lambda_{t}^{2}+\epsilon_{i t}^{2}(2) \\
\ln \operatorname{HumK}_{i t}= & \alpha^{3} \ln M A_{i t}+\psi^{3} \operatorname{CONTROL} S_{i t}^{3}+\eta_{i}^{3}+\lambda_{t}^{3}+\epsilon_{i t}^{3}(3) \\
\ln \operatorname{Experf}_{i t}= & \alpha^{4} \ln M A_{i t}+\kappa^{4} C O N T R O L S_{i t}^{4}+\eta_{i}^{4}+\lambda_{t}^{4}+\epsilon_{i t}^{4}(4) \\
\ln M A_{i t}= & \mu^{5} I_{M A_{i t}^{1}}+\nu^{5} I_{M A_{i t}^{2}}+\eta_{i}^{5}+\lambda_{t}^{5}+\epsilon_{i t}^{5}(5)
\end{aligned}
$$

The first equation (reported in Column 1 of Table 4) corresponds to the wage equation which includes $M A$ and the three indirect channels as regressors. The two indicators of population size and composition are not introduced as they turned out to be insignificant (Column 6 of Table 2). These factors may however have a significant impact on outward orientation and capital accumulation. Columns 2 to 4 report the results for the three channel equations describing the indirect effects of market access on wages, where CONTROLS correspond to the control variables introduced in Table 3. Column 5 determines the exogenous component of market access based on the two instruments $I_{M A^{1}}$ and $I_{M A^{2}}$ discussed above. This set of equations brings together the different theoretical arguments on the potential channels through which economic geography affects wages. We do not assume that these three channels together will adequately capture all of the effect of market access on wages. We therefore include $M A$ in Equation (1) in addition to the three indirect impact variables to capture any residual effect. Our estimations, as is apparent in the equation system presented above, focus on the analysis of the direct and indirect impact of $M A$ on wages. They thus rely on some straightforward assumptions in terms of exclusion restrictions for the three channels of impact. In particular, we hypothesize that those channels are exogenous to wages.

In Column 1, since the channel variables are also included in the wage regression, the coefficient on $M A$ only captures any direct impact which does not transit through capital accumulation or export performance. 
The parameters of the model are jointly estimated using the seemingly unrelated regression (SUR) method. Fixed effects by year and by province are included to account for unobserved location and time effects.

The second panel of Table 4 includes provincial lagged GDP as an additional regressor in the wage equation in order to further test the robustness of the results. This helps to ensure the economic significance of total demand beyond local economic performance. The results are very consistent with the theoretical predictions, both in terms of the impact and the determinants of the three channels.

Our estimates are similar to those from the single equations, with the exception of the insignificant impact of human capital on wages. Moreover, education appears to play no role as a channel of the influence of MA on wages. However, physical capital and export performance do both exert a positive impact on wages and are themselves influenced by MA.

Table 5 summarises the direct and indirect effects from the three channels on wages, the effect of market access on each channel, and the product of the two coefficients. The estimates correspond to the left-hand panel of Table 4. Standardized beta coefficients are reported to ease the comparison between the channels of impact ${ }^{20}$ The results suggest a beneficial total effect of market access on wages. A one standard deviation rise in market access is associated with a 0.2 standard deviation increase in the annual average wage. A fair share of the market access effect on wages transits via increased incentives for accumulating physical capital and exporting (25 and 15 percent of the total effect respectively). Direct transport effects remain however the main source of influence, accounting for almost 60 percent of the total. To better understand the size of these impacts we compute the change in wages were Xinjiang to obtain the same market access as Guangdong (which was ten times larger in 2002). The ten-fold increase in market access in the far-West province of Xinjiang leads to a $60 \%$ rise in wages, bringing Xinjiang level with Zhejiang in third place in China. A ten-fold increase in market access is however not very likely. The average growth rate of market access of Chinese provinces is far much lower at $1.1 \%$ per year between 1995 and 2002. By contrast, provincial wages increased on average by about $13 \%$ per year over the same period. As a consequence, the wage increasing impact of market access appears on average to be small in magnitude. The wage disparity increasing impact of market access seems however to be more significant. Over the sample period, the evolution of MA has been quite heterogenous with high MA provinces experiencing the fastest increase in access to domestic and international markets. For example, the growth rate is $10 \%$ or higher per year in the high MA provinces of Beijing, Guangdong and Zhejiang (refer to Figure 1). To illustrate the wage inequality widening effect of MA, we compute the change in wage difference between Guangdong and Liaoning (in 2002 the average wage in Guangdong is 1.7 times that in Liaoning), were those two provinces to keep the average MA growth

\footnotetext{
${ }^{20}$ The coefficients and standard errors from Table 4 are multiplied by the ratio of the standard deviation of the channel to that of wages in the case of the column (1), and by the ratio of the standard deviation of market access to that of the channel.
} 
rate of 15 and $1.2 \%$ respectively. Over a 5 year period, the MA of Guangdong doubles while that of Liaoning increases by only $6 \%$. This leads to an increase in the average wage of 6 and $0.4 \%$ respectively for Guangdong and Liaoning. The wage ratio between the two provinces would everything else equal rise from 1.7 to 1.8 as a consequence.

\section{Conclusion}

Although China has experienced unprecedented income growth over the last two decades and is still influenced by Maoist egalitarian ideology, income inequalities in the country are large and growing (Meng et al., 2005). This paper has examined one potential explanation of this phenomenon: firms located in remote locations pay greater trade costs on both their sales to final markets and their purchases of intermediate inputs, so that they have less value added available to remunerate domestic factors of production. We compute a complete indicator of market access at the provincial level from data on domestic and international trade flows, and introduce it in a simultaneous-equation system to identify the direct and indirect effects of market access on wages.

Estimations on 29 Chinese provinces over 1995-2002 suggest that access to the sources of demand is indeed an important factor in shaping regional wages. A fair share of the market access effect seems to come from increased incentives to export and accumulate physical capital. There appears to be no influence through education. Direct transport cost advantages remain the main source of influence.

Considering that market access has a significant international component, it is likely that, with further integration into the world economy, these inequalities will grow if access to new markets is not evenly distributed across the country. The already pervasive spatial-wage differences will increase directly through lower trade costs, and indirectly through enhanced incentives to export and accumulate physical capital. This will come to pass if the relative market access of remoter regions deteriorates following further opening, as has been the case over our sample period. We found that while the wage increasing impact of market access appears on average to be small in magnitude, the wage disparity increasing impact of market access seems to be more significant since high market access provinces are the ones characterized with the most rapid improvement. Nevertheless, the impact of market access on wages may well change over time. More research with data spanning a greater number of years is needed to ascertain the wage response to changing market access. 
The impact of economic geography on wages: disentangling the channels of

influence

\section{References}

Alesina, A., E. Spolaore, and R. Wacziarg, 2000, "Economic Integration and Political Disintegration”, American Economic Review 90(5):127696.

Baldwin, R., R. Forslid, P. Martin, G. Ottaviano and F. Robert-Nicoud, 2003, Economic Geography and Public Policy. Princeton: Princeton University Press.

Barro, R., and X. Sala-i Martin, 1997, “Technological Diffusion, Convergence, and Growth.” Journal of Economic Growth, 2(1):126.

Bowsher C., 2002, “On Testing Overidentifying restrictions in Dynamic Panel Data Models", Economic Letters, 77, 211-20.

Breinlich, H., 2006, "The Spatial Income Structure in the European Union - What Role for Economic Geography?", Journal of Economic Geography, 6(5), 593-617.

Brakman, S., H. Garretsen and M. Schramm, 2004, “The spatial distribution of wages and Employment: Estimating the Helpman-Hanson model for Germany", Journal of Regional Science, 44(3), 437-466.

Ciccone, A., 2002, "Agglomeration Effets in Europe", European Economic Review 46, 213237.

Combes P.-P., G. Duranton, and L. Gobillon, 2004, "Spatial wage disparities: Sorting matters!", CEPR Discussion Paper 4240.

Cui F., 2006, "Geographic Location And Regional Income Inequality In China”, mimeo LSE.

De Sousa J. and S. Poncet, 2007, "How are wages set in Beijing?", CEPII, working paper, 2007-13.

De Bruyne, K. 2003, “The Location of Economic Activity: Is there a Spatial Employment Structure in Belgium?", mimeo, K. U. Leuven.

Démurger, S. 2001 "Infrastructure Development and Economic Growth: An Explanation for Regional Disparities in China?", Journal of Comparative Economics, Vol. 29, No. 1, March, pp. 95-117.

Démurger S., Fournier M. and Yi C., 2005, "Earnings differentials and ownership structure in Chinese enterprises", Economic Development and Cultural Change, Vol. 53, No. 4.

Dixit A. K., and Stiglitz J.E., 1977, "Monopolistic competition and optimum product diversity”, American Economic Review, 67, 297-308.

Edwards, S., 1998, “Openness, Productivity and Growth : What Do We Really Know?", Economic Journal 108, 383-398.

Edwards, S., 1992, "Trade Orientation, Distortions and Growth in Developing Countries", Journal of Development Economics 39(1):3157.

Erkel-Rousse, Hélène, and Daniel Mirza, "Import elasticities: reconsidering the evidence", Canadian Journal of Economics 35:2 (2002), 282-306.

Faiña, A., and Lopez-Rodriguez, J., 2006, "Market Access and Human Capital Accumulation: The European Union Case", Applied Economics Letters, 13 (9) p. 563-567. 
Feenstra R., Wen Hai, Wing T. Woo and Shunli Yao. "The U.S.-China Bilateral Trade Balance: Its Size and Determinants", May 1998, with Short version published in American Economic Review, May 1999, 338-343.

Frankel, Jeffrey and David Romer, 1999, "Does trade cause growth?", American Economic Review vol 89, 3, 379-399.

Fujita, M., P. Krugman and A.J. Venables, 1999, The Spatial Economy: Cities, Regions and International Trade, MIT Press, Cambridge MA.

Grossman, G. M., and E. Helpman, 1991, Innovation and Growth in the Global Economy. Cambridge: MIT Press.

Hanson, G., 2005, “Market Potential, Increasing Returns, and Geographic Concentration”, Journal of International Economics 67(1), 124.

Harris, C., 1954, "The Market as a Factor in the Localization of Industry in the United States", Annals of the Association of American Geographers, 64, pp. 315-348.

Head, K. and T. Mayer (2004), The Empirics of Agglomeration and Trade, in Henderson V. and J.F. Thisse (eds.) Handbook of Regional and Urban Economics Volume 4, Amsterdam: Elsevier, chapter 59, pp 2609-2669.

Head, K. and T. Mayer (2006), "Regional Wage and Employment Responses to Market Potential in the EU", Regional Science and Urban Economics, 36(5), 573-594.

Head, Keith, and John Ries, "Increasing Returns Versus National Product Differentiation as an Explanation for the Pattern of US-Canada Trade", American Economic Review 91:4 (2001), 858-876.

Hering L. and S. Poncet, 2008, "Market access and individual wages: evidence from China", Review of Economics and Statistics, forthcoming.

Hering L. and S. Poncet, 2007, "Spatial Income structure in China: The Role of Economic Geography and Spatial Interaction", mimeo.

Krugman P, 1991, "Increasing Returns and Economic Geography", Journal of Political Economy, 99, 483-499.

Krugman P, and Venables A.J, 1995, “Globalization and the Inequality of Nations", Quarterly Journal of Economics, 857-880.

Lin S., 2005, Geographic Location, Trade and Income Inequality in China, in Spatial Inequality and Development, Ravi Kabur and Tony Venables, ed., Oxford University Press, London.

López-Rodriguez, J., and Faiña, A., 2006, "Does distance matter for determining regional income in the European Union? An approach through the market potential concept", Applied Economics Letters, 13 (6), p.385-390.

Ma, Alyson C., 2006, "Geographical Location of Foreign Direct Investment and Wage Inequality in China", World Economy 29:8, 1031-1055.

Meng Xin, Gregory Robert and Wang Youjian, 2005, "Poverty, inequality and growth in urban China, 1986-2000”, Journal of Comparative Economics, vol 33 (4), pages 710729.

Mion G., 2004, "Spatial Externalities and Empirical Analysis: The Case of Italy", Journal of Urban Economics, 56, 97-118. 
The impact of economic geography on wages: disentangling the channels of

influence

National Bureau of Statistics, China Statistical Yearbooks, People's Republic of China. Beijing, China Statistical Press, various years.

National Bureau of Statistics, China Labour Statistical Yearbook, People's Republic of China. Beijing, China Statistics Press, various years.

National Bureau of Statistics, Cities China 1949-1998, Xin Zhongguo Chengshi 50 Nian, People's Republic of China, Beijing: Xinhua Press, 1999

Naughton, Barry, 2007, The Chinese Economy: Transitions and Growth. The MIT Press. Cambridge, Massachusetts. London, England

Pagan, A., 1984, Model Evaluation by Variable Addition. ch 5, pp 103-134 in D.F. Hendry and K.F. Wallis (eds) Econometrics and Quantitative Economics, Blackwell: Oxford.

Poncet, S. 2006, "Provincial Migration dynamics in China: Borders, Centripetal Forces and Trade", Regional Science and Urban Economics, 36 (3), 385-398.

Poncet, S., 2005, "A Fragmented China : Measure and Determinants of China's Domestic Market Disintegration", Review of International Economics, 13 (3), pp. 409-430

Poncet, S., 2003, "Measuring Chinese domestic and international integration", China Economic Review, 14 (1), 1-21.

Redding, S, and Schott P, 2003, "Distance, Skill Deepening and Development: Will Peripheral Countries Ever Get Rich?", Journal of Development Economics, 72(2), 51541.

Redding, S. and Venables A. J., 2003, "South-East Asian Export Performance: External Market Access And Internal Supply Capacity", Journal of the Japanese and International Economies 2003, v17 (4), 404-441.

Redding S, Venables A. J., 2004, "Economic geography and international inequality", Journal of International Economics, 62, (1), 53-82.

Staiger D. and J. H. Stock, 1997, "Instrumental variables regression with weak instruments", Econometrica, 65 (3), p. 557-586.

Stock J. H. and M. Yogo, 2002, "Testing for weak instruments in linear IV regression", NBER technical working paper 284.

Wacziarg R., 2001, "Measuring the dynamic gains from trade", World Bank Economic Review, 15 (3), pp. 393-429. 


\section{Appendix A}

\section{Description of Data}

International trade flows are in current USD and come from IMF Direction of Trade Statistics (DOTS).

Internal trade flows are in current USD and are calculated as the difference between domestic primary- and secondary-sector production minus exports.

Production data for OECD countries come from the OECD STAN database. For other countries, ratios of industry and agriculture output as a percentage of GDP are extracted from Datastream. These are then multiplied by the country's GDP (in current USD) from the World Development Indicators 2005.

Production data for Chinese provinces are computed as the sum of industrial and agricultural output. Output in yuan are converted into current USD using the annual exchange rate. All statistics come from the China Statistical Yearbooks.

Provincial input-output tables ${ }^{21}$ provide the decomposition of provincial output, and international and domestic trade of tradable goods. These are available for 28 provinces, as data are missing for Tibet, Hainan and Tchongqing.

Provincial foreign trade data come from the Customs General Administration database, which records the value of all import and export transactions which pass through Customs. Provincial imports and exports are disaggregated into those from up to 230 international partners. This database has been discussed in Lin (2005) and Feenstra, Hai, Woo and Yao (1998).

Statistics at the province level such as exports, investment flows, schooling rates, infrastructure and population are mainly obtained from two sources: (1) various issues of the Urban Statistical Yearbook, published by China's State Statistical Bureau; and (2) Fifty Years of the Cities in New China: 1949-1998, also published by the State Statistical Bureau.

Table A-1: Summary statistics for wages, market access and the indirect channels

\begin{tabular}{||l||c|c|c|c||}
\hline \hline & Mean & Standard deviation & Minimum & Maximum \\
Wage & 7990 & 3217 & 3,532 & 21,852 \\
MA & 0.011 & 0.025 & 0.001 & 0.18 \\
Population (thousands) & 4242 & 2785 & 481 & 11780 \\
Children dependency ratio & 0.35 & 0.08 & 0.14 & 0.53 \\
Share of population with & 0.04 & 0.04 & 0.01 & 0.28 \\
higher education & & & & \\
Export rate & 0.14 & 0.16 & 0.02 & 0.86 \\
Capital stock per capita & 206 & 177 & 39 & 1112 \\
\hline
\end{tabular}

\footnotetext{
${ }^{21}$ Most Chinese provinces produced square input-output tables for 1997. A few of these are published in provincial statistical yearbooks. We obtained access to the final-demand columns of these matrices from the input-output division of China's National Bureau of Statistics. Our estimations assume that the share of domestic trade flows (that is between each province and the rest of China) in the total trade of provinces is constant over time.
} 
The impact of economic geography on wages: disentangling the channels of influence

Table A-2: Summary statistics for wages

\begin{tabular}{||l||c|c|c||}
\hline \hline Province & 1995 & 2002 & Average yearly growth rate in \% \\
\hline Beijing & 7233 & 21852 & 17.1 \\
Tianjin & 6501 & 16223 & 14.0 \\
Hebei & 4839 & 8959 & 9.2 \\
Shanxi & 4721 & 9357 & 10.3 \\
Inner Mongolia & 3532 & 9683 & 15.5 \\
Liaoning & 4877 & 11659 & 13.3 \\
Jilin & 4430 & 9990 & 12.3 \\
Heilongjiang & 4145 & 9926 & 13.3 \\
Shanghai & 7817 & 19473 & 13.9 \\
Jiansgu & 5943 & 13509 & 12.4 \\
Zhejiang & 5658 & 18227 & 18.2 \\
Anhui & 4609 & 9296 & 10.5 \\
Fujian & 5084 & 13306 & 14.7 \\
Jiangxi & 4211 & 9262 & 11.9 \\
Shandong & 4375 & 11374 & 14.6 \\
Henan & 4344 & 9174 & 11.3 \\
Hubei & 3901 & 9611 & 13.7 \\
Hunan & 4797 & 8734 & 8.9 \\
Guangdong & 8250 & 17814 & 11.6 \\
Guanxi & 5105 & 10774 & 11.3 \\
Hainan & 5340 & 9480 & 8.5 \\
Guizhou & 4475 & 9810 & 11.9 \\
Yunnan & 5149 & 11987 & 12.8 \\
Sichuan & 4645 & 11119 & 13.3 \\
Shaanxi & 4396 & 10351 & 13.0 \\
Gansu & 5493 & 10272 & 9.4 \\
Qinghai & 5753 & 14472 & 14.1 \\
Ningxia & 5079 & 11723 & 12.7 \\
Xinjiang & 4468 & 11605 & 14.6 \\
\hline \hline
\end{tabular}


Table 1: Trade equation estimations

\begin{tabular}{||l|c|c|c||}
\hline \hline & \multicolumn{3}{|c||}{ Dependent Variable: Ln Exports } \\
\hline & Column 1 & Column 2 & Column 3 \\
\hline \multicolumn{4}{|c|}{ Fixed effects by exporter } \\
\multicolumn{4}{|c|}{ Fixed effects by importer } \\
\hline Ln Distance & -1.24 & -1.28 & -1.34 \\
& $(0.02)^{* * *}$ & $(0.02)^{* * *}$ & $(0.02)^{* * *}$ \\
China Domestic Border & -1.77 & -3.05 & -2.52 \\
Effect & $(0.56)^{* * *}$ & $(0.61)^{* * *}$ & $(0.65)^{* * *}$ \\
China Foreign Border & -4.72 & -4.79 & -3.94 \\
Effect & $(0.28)^{* * *}$ & $(0.31)^{* * *}$ & $(0.33)^{* * *}$ \\
& -2.82 & -2.77 & -2.28 \\
Foreign country Border & $(0.28)^{* * *}$ & $(0.30)^{* * *}$ & $(0.32)^{* * *}$ \\
Effect & 1.60 & 1.57 & 1.56 \\
Contiguity & $(0.10)^{* * *}$ & $(0.11)^{* * *}$ & $(0.11)^{* * *}$ \\
\hline No. of Observations & 21442 & 24143 & 23146 \\
\hline R-squared & 0.38 & 0.40 & 0.40 \\
\hline \multicolumn{4}{|c|}{ Hen } \\
\hline
\end{tabular}

Heteroskedastic-consistent standard errors in parentheses;

***, ${ }^{* *}$ and ${ }^{*}$ denote significance at the 1,5 and $10 \%$ levels respectively. 
The impact of economic geography on wages: disentangling the channels of influence

\section{Map 1: Provincial Market Access and Wages}

Yearly Manufacturing Wage (Muans) in 2002

Top quintile 22.000

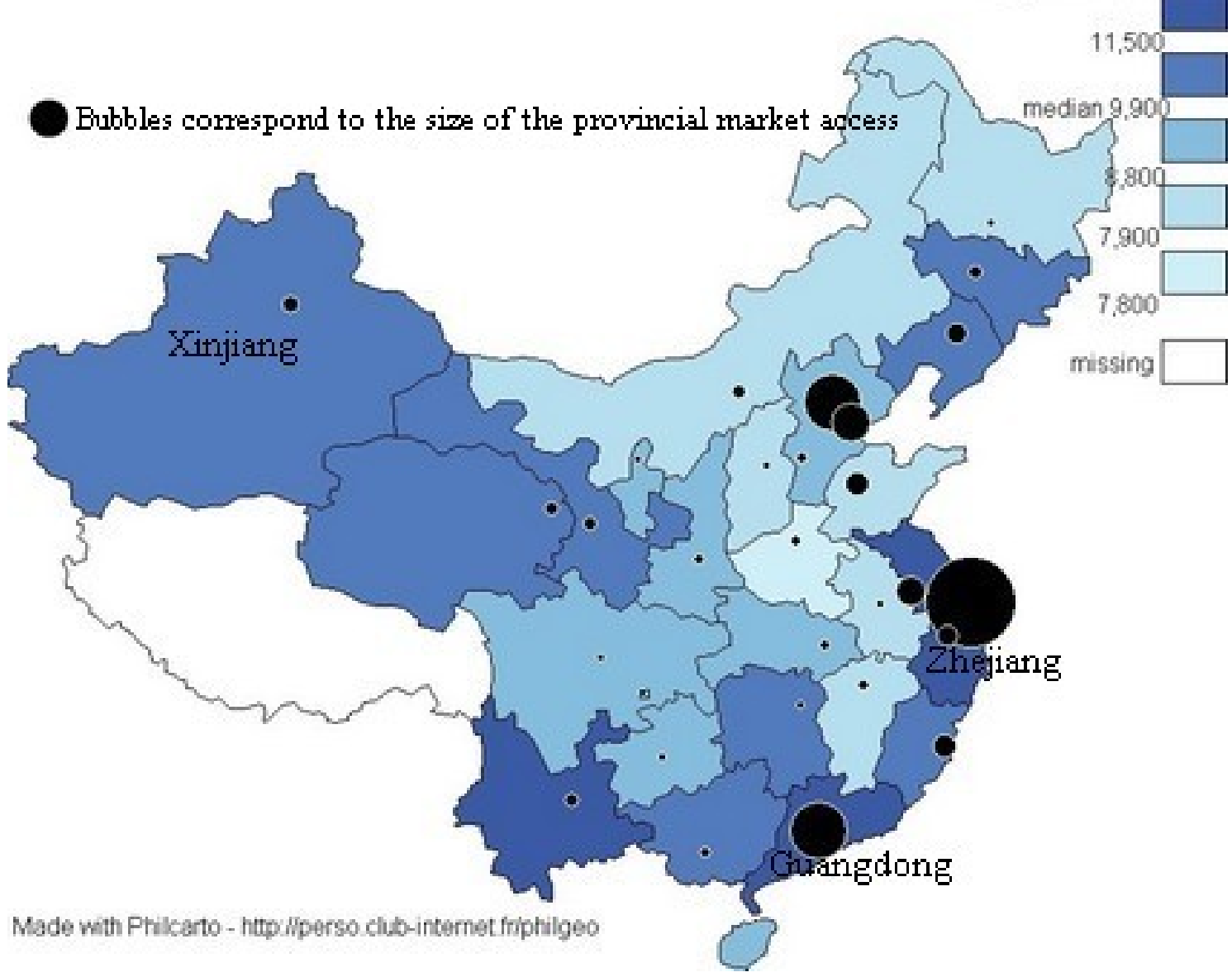


Market access and average wages (1995 and 2002)

Figure 1: Market access and average wages (1995)

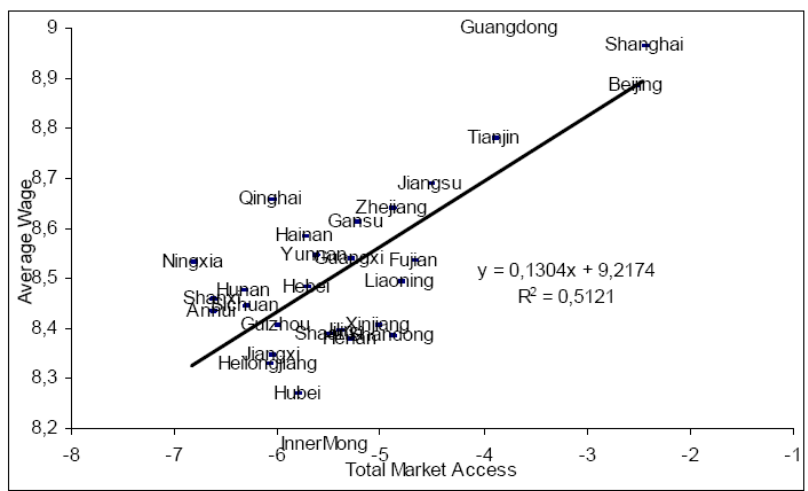

Figure 2: Market access and average wages (2002)

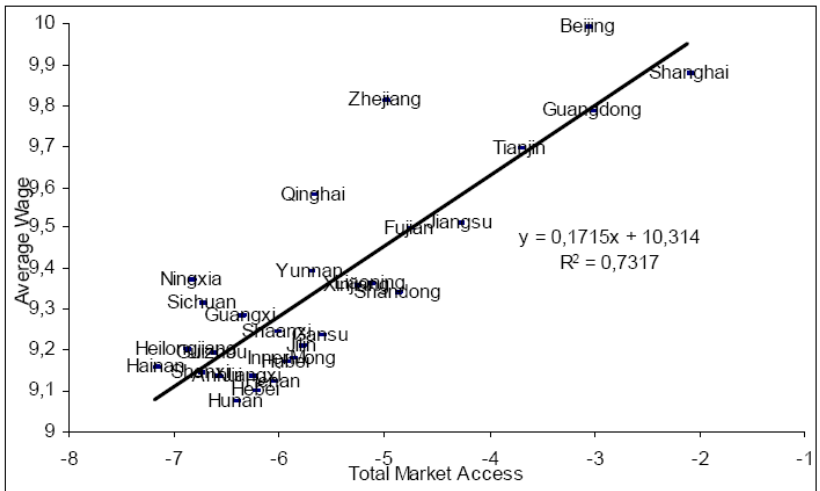


The impact of economic geography on wages: disentangling the channels of

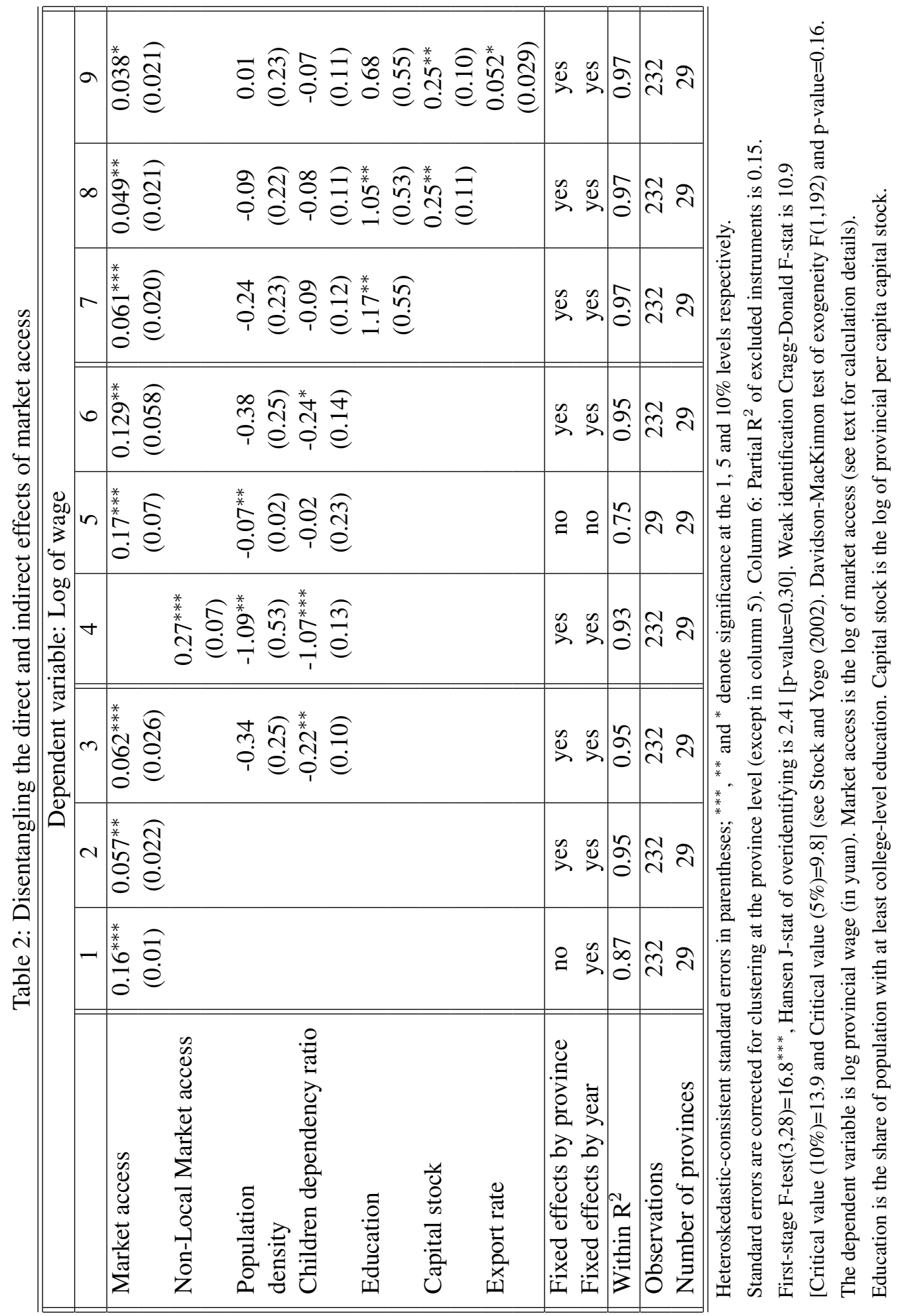


CEPII, Working Paper No 2008-20. 
The impact of economic geography on wages: disentangling the channels of

Table 3: Impact of market access on other determinants of wages

\begin{tabular}{|c|c|c|c|}
\hline \multicolumn{4}{|c|}{ Estimation Method Within } \\
\hline Dependent variable & $\begin{array}{c}\text { Education } \\
1\end{array}$ & $\begin{array}{c}\text { Capital per capita } \\
2\end{array}$ & $\begin{array}{c}\text { Export rate } \\
3\end{array}$ \\
\hline Market access & $\begin{array}{c}0.01 \\
(0.01)\end{array}$ & $\begin{array}{c}0.05^{* * *} \\
(0.02)\end{array}$ & $\begin{array}{c}0.20^{* * *} \\
(0.06)\end{array}$ \\
\hline $\begin{array}{l}\text { Population } \\
\text { density }\end{array}$ & & & $\begin{array}{l}-3.06 \\
(1.85)\end{array}$ \\
\hline Children dependency ratio & $\begin{array}{c}-0.10^{* * *} \\
(0.02)\end{array}$ & $\begin{array}{l}-0.12 \\
(0.08)\end{array}$ & $\begin{array}{c}-0.26^{* *} \\
(0.11)\end{array}$ \\
\hline Temperature & $\begin{array}{l}-0.01^{* *} \\
(0.005)\end{array}$ & $\begin{array}{c}-0.003^{* *} \\
(0.001)\end{array}$ & \\
\hline $\begin{array}{l}\text { Share of state entities } \\
\text { in investment }\end{array}$ & & $\begin{array}{c}0.08 \\
(0.06)\end{array}$ & \\
\hline $\begin{array}{l}\text { Infrastructure in } \mathrm{km} \\
\text { per capita }\end{array}$ & & & $\begin{array}{c}0.38^{* *} \\
0.17\end{array}$ \\
\hline $\begin{array}{l}\text { Share of state entities } \\
\text { in industrial output }\end{array}$ & & & $\begin{array}{c}-0.21^{* * *} \\
(0.06)\end{array}$ \\
\hline $\begin{array}{l}\text { Fixed effects by province } \\
\text { Fixed effects by year }\end{array}$ & $\begin{array}{l}\text { yes } \\
\text { yes }\end{array}$ & $\begin{array}{l}\text { yes } \\
\text { yes }\end{array}$ & $\begin{array}{l}\text { yes } \\
\text { yes }\end{array}$ \\
\hline $\begin{array}{l}\text { Observations } \\
\text { Number of provinces }\end{array}$ & $\begin{array}{c}232 \\
29\end{array}$ & $\begin{array}{c}232 \\
29\end{array}$ & $\begin{array}{c}232 \\
29\end{array}$ \\
\hline Within $\mathrm{R}^{2}$ & 0.74 & 0.96 & 0.42 \\
\hline $\begin{array}{l}\text { Hansen test of overidentifying } \\
\text { restrictions ( } \mathrm{Chi}^{2} \text { and p-value) }\end{array}$ & $\begin{array}{l}1.21 \\
0.27\end{array}$ & $\begin{array}{l}2.43 \\
0.30\end{array}$ & $\begin{array}{l}1.07 \\
0.59\end{array}$ \\
\hline $\begin{array}{l}\text { Tests for Weak identification } \\
\text { Cragg-Donald F-stat }\end{array}$ & 10.1 & 10.0 & 10.4 \\
\hline $\begin{array}{l}\text { Davidson-MacKinnon test of } \\
\text { exogeneity (F-stat and p-value) }\end{array}$ & $\begin{array}{l}0.02 \\
0.89\end{array}$ & $\begin{array}{l}0.50 \\
0.48\end{array}$ & $\begin{array}{l}1.90 \\
0.17\end{array}$ \\
\hline
\end{tabular}

Notes: OLS estimates are reported; Standard errors (in parentheses) are corrected for clustering ; at the province level ${ }^{* * *},{ }^{* *}$ and ${ }^{*}$ denote significance at the 1,5 and $10 \%$ levels respectively. 
CEPII, Working Paper No 2008-20.

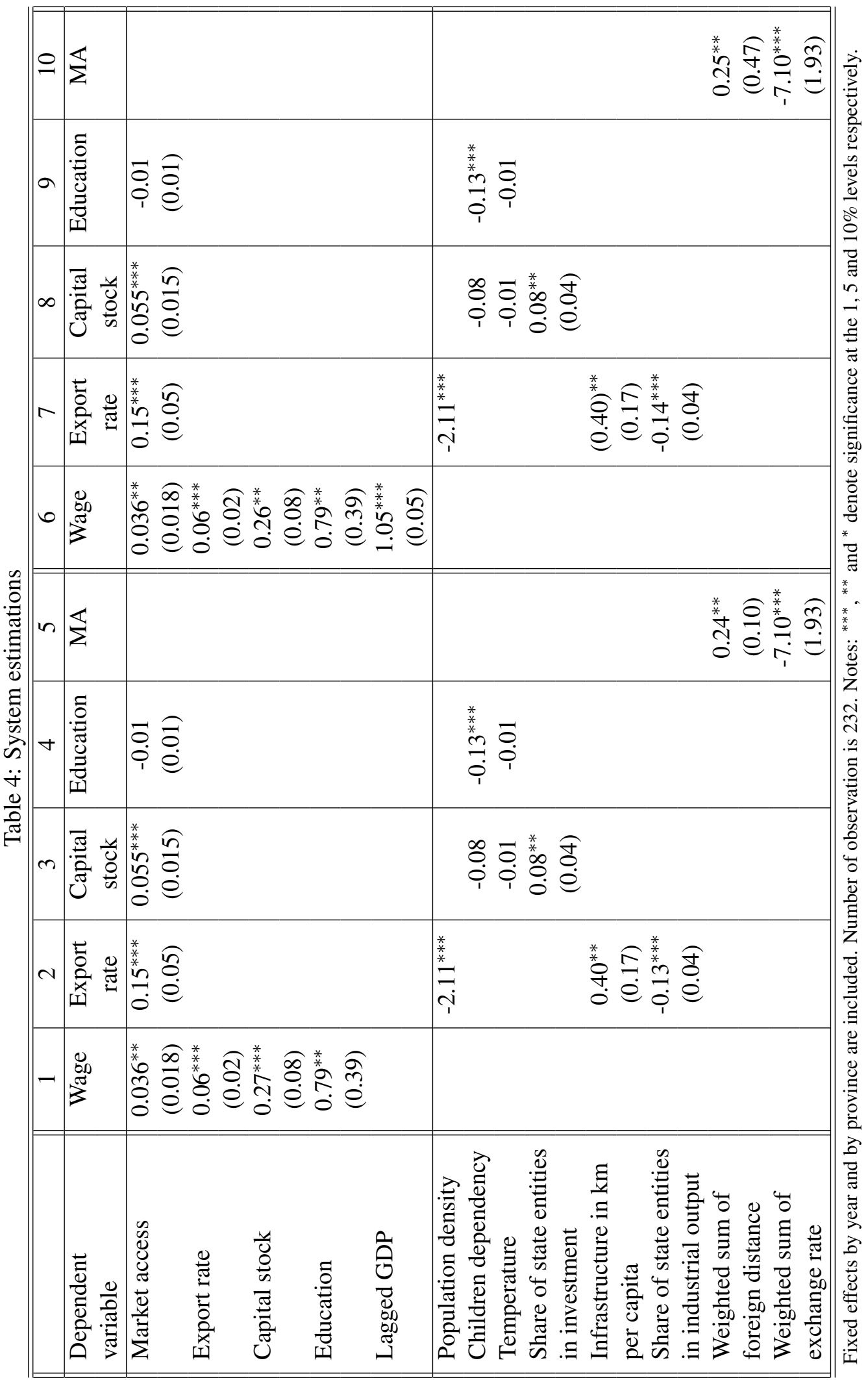


The impact of economic geography on wages: disentangling the channels of influence

Table 5: Summary of the direct and indirect effects of market access on wages: standardized beta coefficients

\begin{tabular}{||l||c|c|c|c||}
\hline \hline Channel & $\begin{array}{c}\text { Effect of } \\
\text { channel on wage }\end{array}$ & $\begin{array}{c}\text { Effect of } \\
\text { on channel }\end{array}$ & $\begin{array}{c}\text { Effect of MA } \\
\text { access on wage }\end{array}$ & Percentage \\
\hline Export rate & 1 & 2 & $3=(1)^{*}(2)$ & 4 \\
Capital stock & 0.14 & 0.214 & 0.031 & $15 \%$ \\
& 0.05 & 0.071 & & \\
Education & 0.50 & 0.101 & 0.051 & $25 \%$ \\
& 0.15 & 0.028 & & \\
Direct impact & 0.09 & -0.290 & 0.000 & $0 \%$ \\
& 0.12 & 0.290 & & $60 \%$ \\
\hline Total Effect & 0.07 & & 0.12 & $100 \%$ \\
\hline \hline
\end{tabular}

Notes: The coefficients and standard errors in this table are based on the results from the left-hand side of Table 4. 


\section{LIST OF WORKING PAPERS RELEASED BY CEPII ${ }^{1}$}

No

Title

Authors

2008-19 Do Corporate Taxes Reduce Productivity and Investment at the Firm Level? Cross-Country Evidence from the Amadeus Dataset

J. Arnold \&

C. Schwellnu

2008-18 Choosing Sensitive Agricultural Products in Trade Negotiations

S. Jean, D. Laborde \& W. Martin

D. Furceri

2008-17 Government Consumption Volatility and Country Size \& M. Poplawski

Ribeiro

2008-16 Inherited or Earned? Performance of Foreign Banks in Central and Eastern Europe

O. H avrylchyk \& E. Jurzyk

2008-15 The Effect of Foreign Bank Entry on the Cost of Credit in Transition Economies. Which Borrowers Benefit most?

H. Degryse, O. Havrylchyk,

2008-14 Contagion in the Credit Default Swap Market: the Case of the GM and Ford Crisis in 2005.

2008-13 Exporting to Insecure Markets: A Firm-Level Analysis

2008-12 Social Competition and Firms' Location Choices

2008-12 Social Competition and Firms' Location Choices E. Jurzyk \& S. Kozak

V. Coudert \& M. Gex

M. Crozet, P. Koenig \& V. Rebeyrol

V. Delbecque, I. Méjean \& L. Patureau

V. Delbecque, I. Méjean \& L. Patureau

2008-11 Border Effects of Brazilian States

M. Daumal \& S. Zignago

2008-10 International Trade Price Indices

G. Gaulier, J. Martin, I. Méjean \& S. Zignago

2008-10 International Trade Price Indices

G. Gaulier, J. Martin,

I. Méjean \& S. Zignago

\footnotetext{
${ }^{1}$ Working papers are circulated free of charge as far as stocks are available; thank you to send your request to CEPII, Sylvie Hurion, 9, rue Georges-Pitard, 75015 Paris, or by fax : (33) 0153685504 or by e-mail Hurion@cepii.fr. Also available on: ॥www.cepii.fr. Working papers with* are out of print. They can nevertheless be consulted and downloaded from this website.
} 
The impact of economic geography on wages: disentangling the channels of influence

2008-09 Base de données CHELEM - Commerce international du CEPII

2008-08 The Brain Drain between Knowledge Based Economies: the European Human Capital Outflows to the US

2008-07 Currency Misalignments and Exchange Rate Regimes in Emerging and Developing Countries

2008-06 The Euro and the Intensive and Extensive Margins of Trade: Evidence from French Firm Level Data

2008-05 On the Influence of Oil Prices on Economic Activity and Other Macroeconomic and Financial Variables

2008-04 An Impact Study of the EU-ACP Economic Partnership Agreements (EPAs) in the Six ACP Regions

2008-03 The Brave New World of Cross-Regionalism

2008-02 Equilibrium Exchange Rates: a Guidebook for the Euro-Dollar Rate

2008-01 How Robust are Estimated Equilibrium Exchange Rates? A Panel BEER Approach

2007-24 Testing the Finance-Growth Link: Is there a Difference between Developed and Developing Countries?

2007-23 Labor Migration: Macoeconomic and Demographic outlook for Europe and Neighborhood Regions

2007-22 Economic Geography, Spatial Dependence and Income Inequality in China

2007-21 Does FDI in Manufacturing Cause FDI in Business Services? Evidence from French Firm-Level Data

2007-20 Bilateral Trade of Cultural Goods

2007-19 China and India in International Trade: from Laggards to Leaders?
A. de Saint Vaulry

A. Tritah

V. Coudert

\& C. Couharde

A. Berthou

\& L. Fontagné

F. Lescaroux

\& V. Mignon

L. Fontagné,

D. Laborde

\& C. Mitaritonna

A. Tovias

A. Bénassy-Quéré,

S. Béreau

\& V. Mignon

A. Bénassy-Quéré,

S. Béreau

\& V. Mignon

G. Dufrénot,

V. Mignon

\& A. Péguin-Feissolle

V. Borgy

\& X. Chojnicki

L. Hering

\& S. Poncet

B. Nefussi

\& C. Schwellnus

A.C. Disdier,

S.H.T. Tai,

L. Fontagné

\& T. Mayer

F. Lemoine

\& D. Ünal-Kesenci 


\section{CEPII \\ DOCUMENTS DE TRAVAIL / WORKING PAPERS}

Si vous souhaitez recevoir des Documents de travail, merci de remplir le coupon-réponse ci-joint et de le retourner à :

Should you wish to receive copies of the CEPII's Working papers, just fill the reply card and return it to:

Sylvie HURION - Publications

CEPII - 9, rue Georges-Pitard - 75740 Paris - Fax : (33) 1.53.68.55.04

sylvie.hurion@cepii.fr

M./Mme / Mr./Mrs

Nom-Prénom / Name-First name

Titre / Title

Service / Department

Organisme / Organisation

Adresse / Address.

Ville \& CP / City \& post code.

Pays / Country...... Tél.

Your e-mail

Désire recevoir les Document de travail du CEPII $n^{\circ}$ :

Wish to receive the CEPII's Working Papers No:

Souhaite être placé sur la liste de diffusion permanente (pour les bibliothèques)

Wish to be placed on the standing mailing list (for Libraries). 